\title{
Microvessel density is as a prognostic factor in canine cutaneous mast cell tumors
}

\author{
Daniella FL Barbosa', Lidia H Pulz², Nilton P Santos ${ }^{1}$, Silvia Regina Kleeb³ ${ }^{3}$ José Guilherme Xavier ${ }^{4}$, \\ José Luiz Catão-Dias ${ }^{1}$, Ricardo F Strefezzi ${ }^{1 *}$ \\ From São Paulo Advanced School of Comparative Oncology \\ Águas de São Pedro, Brazil. 30 September - 6 October 2012
}

\section{Background}

Mast cell tumors represent almost $25 \%$ of canine skin neoplasms. These tumors are classified in three grades of differentiation, based on histological features. However, this grading system is a method based on subjective parameters, which generate intra- and interobserver variations. The microcirculation is an important feature to the primary tumor expansion, dissemination and metastasis, and there are essential evidences that increasing microvessel density is associated with short survival disease-free intervals. The purpose of the present study was to verify the prognostic value of the intratumoral microvessel density (IMVD) in a set of canine cutaneous mast cell tumors.

\section{Materials and methods}

Twenty-nine canine cutaneous mast cell tumors were subjected to immunohistochemical analysis using a rabbit polyclonal antibody anti-human von Willebrand Factor. Subsequently, the IMVD was determined by the average number of vessels in 5 low-power fields.

\section{Results}

The average IMVD was 9.1 vessels/field for grade I mast cell tumor cases, 14.1 for grade II and 17.2 for grade III. There was no statistically significant differences between histopathological grades with regard to IMVD ( $\mathrm{p}=0.0881$ ). Nevertheless, IMVD was significantly higher $(\mathrm{p}=0.0362)$ in dogs which died due to the mast cell tumor. After the identification of a cutoff point by ROC curve analysis (12.6 vessels/field), cases were divided into two groups. Survival analysis showed that mast cell tumors with higher IMVDs had a worse prognosis $(\mathrm{p}=0.0064)$, with median survival of 751 days.

\section{Conclusions}

The IMVD is a trustworthy prognostic factor, indicating the post-surgical survival in cases of canine cutaneous mast cell tumors.

\section{Financial support}

FAPESP (grant no. 2010/05094-5) and CNPq (PIBIC 2011-459).

\section{Author details}

'Department of Veterinary Medicine, Faculty of Animal Sciences and Food Engineering, University of São Paulo, Pirassununga/SP, Brazil. ${ }^{2}$ Department of Pathology, Faculty of Veterinary Medicine and Animal Sciences, University of São Paulo, São Paulo/SP, Brazil. ${ }^{3}$ Course of Veterinary Medicine, Paulista University, São Paulo/SP, Brazil. ${ }^{4}$ Course of Veterinary Medicine, Metodista University, São Bernardo do Campo/SP, Brazil.

Published: 4 April 2013

doi:10.1186/1753-6561-7-S2-P62

Cite this article as: Barbosa et al:: Microvessel density is as a prognostic factor in canine cutaneous mast cell tumors. BMC Proceedings 2013 7(Suppl 2):P62.

\footnotetext{
* Correspondence: rstrefezzi@usp.br

${ }^{1}$ Department of Veterinary Medicine, Faculty of Animal Sciences and Food

Engineering, University of São Paulo, Pirassununga/SP, Brazil

Full list of author information is available at the end of the article
}

(c) 2013 Barbosa et al; licensee BioMed Central Ltd. This is an Open Access article distributed under the terms of the Creative Commons 